\title{
Transient Receptor Potential Canonical 3 (TRPC3) Is Required for IgG Immune Complex-Induced Excitation of the Rat Dorsal Root Ganglion Neurons
}

\author{
Lintao Qu, ${ }^{1}$ Yumei Li, ${ }^{2}$ Xinghua Pan, ${ }^{2}$ Pu Zhang, ${ }^{1}$ Robert H. LaMotte, ${ }^{1}$ and Chao $\mathrm{Ma}^{1,3}$ \\ Departments of ${ }^{1}$ Anesthesiology and ${ }^{2}$ Genetics, Yale University School of Medicine, New Haven, Connecticut 06510, and ${ }^{3}$ Department of Anatomy, \\ Histology and Embryology, Institute of Basic Medical Sciences, Chinese Academy of Medical Sciences, School of Basic Medicine, Peking Union Medical \\ College, Beijing 100005, China
}

Chronic pain may accompany immune-related disorders with an elevated level of serum IgG immune complex (IgG-IC), but the underlying mechanisms are obscure. We previously demonstrated that IgG-IC directly excited a subpopulation of dorsal root ganglion (DRG) neurons through the neuronal Fc-gamma receptor I (Fc $\gamma \mathrm{RI})$. This might be a mechanism linking IgG-IC to pain and hyperalgesia. The purpose of this study was to investigate the signaling pathways and transduction channels activated downstream of IgG-IC and Fc $\gamma$ RI. In whole-cell recordings, IgG-IC induced a nonselective cation current $\left(\mathrm{I}_{\mathrm{IC}}\right)$ in the rat DRG neurons, carried by $\mathrm{Ca}^{2+}$ and $\mathrm{Na}^{+}$. The $\mathrm{I}_{\mathrm{IC}}$ was potentiated or attenuated by, respectively, lowering or increasing the intracellular $\mathrm{Ca}^{2+}$ buffering capacity, suggesting that this current was regulated by intracellular calcium. Single-cell RT-PCR revealed that transient receptor potential canonical 3 (TRPC3) mRNA was always coexpressed with Fc $\gamma$ RI mRNA in the same DRG neuron. Moreover, ruthenium red (a general TRP channel blocker), BTP2 (a

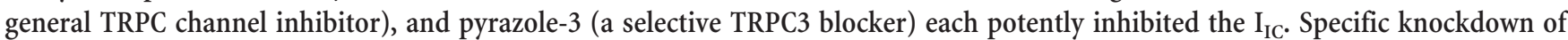
TRPC3 using small interfering RNA attenuated the IgG-IC-induced $\mathrm{Ca}^{2+}$ response and the $\mathrm{I}_{\mathrm{IC}}$. Additionally, the $\mathrm{I}_{\mathrm{IC}}$ was blocked by the tyrosine kinase Syk inhibitor OXSI-2, the phospholipase C (PLC) inhibitor neomycin, and either the inositol triphosphate $\left(\mathrm{IP}_{3}\right)$ receptor antagonist 2-aminoethyldiphenylborinate or heparin. These results indicated that the activation of neuronal Fc $\gamma \mathrm{RI}$ triggers TRPC channels through the Syk-PLC-IP 3 pathway and that TRPC3 is a key molecular target for the excitatory effect of IgG-IC on DRG neurons.

\section{Introduction}

Chronic pain is a major health problem that may accompany numerous immune-related diseases (Moulin, 1998; Mathsson et al., 2006; McDougall, 2006; Wittkowski et al., 2007; Oaklander, 2008; Kaida et al., 2009). The IgG immune complex (IgG-IC) appears to be an important factor for the pathogenesis of such pain in addition to the contributions of inflammatory mediators, such as certain chemokines and cytokines (Mathsson et al., 2006; Kaida et al., 2009). IgG-IC produced cutaneous hyperalgesia after the injection of a foreign antigen into the hindpaws of animals immunized with the same antigen and expressing an elevated

\footnotetext{
Received December 20, 2011; revised May 20, 2012; accepted May 23, 2012.

Author contributions: L.Q., R.H.L., and C.M. designed research; L.Q., Y.L., X.P., P.Z., and C.M. performed research; Y.L. and X.P. contributed unpublished reagents/analytic tools; L.Q., Y.L., X.P., P.Z., and C.M. analyzed data; L.Q., R.H.L., and C.M. wrote the paper.

This work was supported by National Institute of Neurological Disorders and Stroke Grants NS065091 (C.M.) and NS014624 (R.H.L.), by a Research Startup Grant (C.M.) from the Department of Anesthesiology, Yale University School of Medicine, by the Peking Union Medical College, Chinese Academy of Medical Sciences, Institute of Basic Medical Sciences Dean's Fund 2011RC01 (C.M.). L.Q. is the recipient of a fellowship from the Canadian Institutes of Health Research. We thank Dr. Sven-Eric Jordt in the Department of Pharmacology, Yale University School of Medicine, for the gift of HC-030031.

The authors declare no competing financial interests.

Correspondence should be addressed to Chao Ma, Department of Anatomy, Histology and Embryology, Institute of Basic Medical Sciences, Chinese Academy of Medical Sciences, School of Basic Medicine, Peking Union Medical College, Beijing 100005, China. E-mail: chao.ma@yale.edu.

DOI:10.1523/JNEUROSCI.6355-11.2012

Copyright $\odot 2012$ the authors $\quad 0270-6474 / 12 / 329554-09 \$ 15.00 / 0$
}

level of serum IgG (Verri et al., 2008; Ma et al., 2009). However, the neural mechanisms whereby IgG-IC induces pain have not been fully elucidated.

$\mathrm{Fc}$-gamma receptors ( $\mathrm{Fc} \gamma \mathrm{Rs})$, the receptors binding to the $\mathrm{Fc}$ domain of IgG, are typically expressed in immune cells and have been implicated in the pain generated by inducing the release of proinflammatory cytokines from immune cells (Nimmerjahn and Ravetch, 2006, 2008). The Fc $\gamma$ R family consists of two functionally different classes, the activating and the inhibitory receptors. Among them, Fc $\gamma \mathrm{RI}$ is the only high-affinity activating receptor. Recent studies revealed that Fc $\gamma \mathrm{RI}$, but not Fc $\gamma \mathrm{RII}$ or Fc $\gamma$ RIII, is expressed in nociceptive dorsal root ganglion (DRG) neurons (Andoh and Kuraishi, 2004; Qu et al., 2011a). Moreover, neuronal Fc $\gamma$ RI appears to be a key player mediating the direct effect of IgG-IC on DRG neurons. The activation of neuronal Fc $\gamma$ RI by IgG-IC produced an increase in intracellular calcium $\left(\left[\mathrm{Ca}^{2+}\right]_{\mathrm{i}}\right)$ and directly caused the membrane depolarization of DRG neurons (Qu et al., 2011a). However, the ionic mechanisms whereby IgG-IC-evoked activation of Fc $\gamma$ RI leads to neuronal excitation remain unknown.

Our recent study (Qu et al., 2011a) showed that the activation of Fc $\gamma$ RI by IgG-IC decreased the input resistance and depolarized the membrane potential of the DRG neurons, suggesting that the effect of IgG-IC involves the opening of cation channels. In the human monocytic cell line, Fc $\gamma$ RI activation indirectly triggered a nonselective cation channel (NSCC) (Floto et al., 
1997). Furthermore, the activity of this channel was enhanced by the depletion of intracellular $\mathrm{Ca}^{2+}$ stores independently of Fc $\gamma$ RI, suggesting the involvement of a store-operated channel (SOC). However, the molecular identity of this channel is unclear. Transient receptor potential canonical (TRPC) channels (including subtypes $1-7$ ), a family of $\mathrm{Ca}^{2+}$-permeable NSCCs, play a critical role in the regulation of resting membrane potential in excitable cells (Pedersen et al., 2005). All TRPC channels, except TRPC2, are present in rat DRG neurons, with TRPC1, 3, and 6 the most abundant (Kress et al., 2008). Furthermore, some of the TRPCs are activated via a store-operated mechanism (Wu et al., 2010). More recently, TRPC3/6/7 was identified as a key downstream transduction channel in Fc- $\varepsilon$ receptor I (FceRI) signaling in mast cells (Sanchez-Miranda et al., 2010).

Therefore, the present study examined the potential role of TRPC channels in mediating the depolarizing effects of IgG-IC and the associated cellular mechanisms in rat DRG neurons. Preliminary results of this study were presented in abstract form $(\mathrm{Qu}$ et al., 2011b).

\section{Materials and Methods}

Animals. The adult Sprague Dawley rats (120-180 g) used in this study were all female to maintain consistency with our previous studies (Ma and LaMotte, 2005; Ma et al., 2006). Rats were housed in groups of three or four under a $12 \mathrm{~h}$ light/dark cycle. All the experimental procedures were approved by the Institutional Animal Care and Use Committee of Yale University School of Medicine and were conducted in accordance with the guidelines provided by the National Institute of Health and the International Association for the Study of Pain.

Cell dissociation and culture. DRG neurons were cultured from adult Sprague Dawley rats as described previously (Qu et al., 2011a). Briefly, bilateral L4 and L5 lumbar DRGs were harvested from rats and transferred into oxygenated complete saline solution (CSS) for cleaning and mincing. The CSS contained the following (in $\mathrm{mM}$ ): $137 \mathrm{NaCl}, 5.3 \mathrm{KCl}, 1$ $\mathrm{MgCl}_{2}, 3 \mathrm{CaCl}_{2}, 25$ sorbitol, and 10 HEPES, adjusted to $\mathrm{pH} 7.2$ with $\mathrm{NaOH}$. The DRGs were then digested with Liberase TH $(0.19 \mathrm{U} / \mathrm{ml}$; Roche Diagnostics) for $20 \mathrm{~min}$ and for another $20 \mathrm{~min}$ with Liberase TL (0.25 U/ml; Roche Diagnostics) and papain ( $30 \mathrm{U} / \mathrm{ml}$; Worthington Biochemical) in CSS containing $0.5 \mathrm{~mm}$ EDTA at $37^{\circ} \mathrm{C}$. After enzymatic digestion, the cells were dissociated by gentle trituration with a firepolished Pasteur pipette in culture medium containing $1 \mathrm{mg} / \mathrm{ml}$ bovine serum albumin and $1 \mathrm{mg} / \mathrm{ml}$ trypsin inhibitor (Boehringer Mannheim) and placed on poly-D-lysine/laminin-coated glass coverslips (BioCoat; $\mathrm{BD}$ Biosciences). The culture medium contained equal amounts of DMEM and F12 (Invitrogen) with 10\% FCS (HyClone Laboratories) and $1 \%$ penicillin-streptomycin (Invitrogen). The cells were maintained at $37^{\circ} \mathrm{C}$ in a humidified atmosphere of $95 \%$ air and $5 \% \mathrm{CO}_{2}$ and were used within $24 \mathrm{~h}$.

Preparation of IgG immune complex. IgG-IC was prepared as we previously described (Qu et al., 2011a) using the normal mouse IgG (Santa Cruz Biotechnology) as antigen and the affinity-purified rat anti-mouse IgG (Jackson ImmunoResearch) as antibody. To avoid the possible toxic and nonspecific effects of sodium azide on DRG neurons, the storage buffer of all the IgGs (containing sodium azide) was changed to HEPES buffer using Zeba spin desalting columns (Thermo Scientific) before application. IgG-IC was formed by incubating $10 \mu \mathrm{g} / \mathrm{ml}$ antigen and antibody at the ratio of $1: 1$ for $1 \mathrm{~h}$ at $25^{\circ} \mathrm{C}$. Since IgG-IC at the concentration of $0.1 \mu \mathrm{g} / \mathrm{ml}$ displayed the strongest effect on the excitation of DRG neurons in our previous study (Qu et al., 2011a), the concentration of $0.1 \mu \mathrm{g} / \mathrm{ml}$ IgG-IC was used throughout this study.

Calcium imaging. Calcium imaging was performed on cultured rat DRG neurons, as described previously (Qu et al., 2011a). Briefly, DRG neurons were loaded with $2 \mu \mathrm{M}$ Fura 2-acetoxymethyl ester (Invitrogen) in the dark for $45 \mathrm{~min}$ at $37^{\circ} \mathrm{C}$ and then washed twice in a HEPES buffer containing the following (in mM): $145 \mathrm{NaCl}, 3 \mathrm{KCl}, 2 \mathrm{MgCl}_{2}, 2 \mathrm{CaCl}_{2}, 10$ glucose, and $10 \mathrm{HEPES}$, adjusted to $\mathrm{pH} 7.4$ with $\mathrm{NaOH}$. Cells were alternatively excited at 340 and $380 \mathrm{~nm}$ using a Polychrome V Monochroma- tor (TILL Photonics). Images were recorded at $2 \mathrm{~s}$ intervals at room temperature $\left(20-22^{\circ} \mathrm{C}\right)$ using a cooled CCD camera (Sensicam) controlled by a computer with Image Workbench 5.2 software (Indec Biosystems). The ratio of 340 to $380 \mathrm{~nm}$ fluorescence intensity $\left[R_{(340 / 380)}\right]$ within a certain region of interest after background subtraction was used as a relative measure of intracellular calcium concentration $\left(\left[\mathrm{Ca}^{2+}\right]_{\mathrm{i}}\right)$ (Grynkiewicz et al., 1985). Calibration with external standards (Calcium Calibration Buffer Kit; Invitrogen) showed that $R_{(340 / 380)}$ increased linearly with $\left[\mathrm{Ca}^{2+}\right]_{\mathrm{i}}$ up to approximately $1 \mu \mathrm{M}$ and that $R_{(340 / 380)}$ of $0.7-$ 1.25 corresponded to basal $\left[\mathrm{Ca}^{2+}\right]_{\mathrm{i}}$ of $90-180 \mathrm{~nm}$. Therefore, only small diameter neurons ( $\leq 30 \mu \mathrm{m}$ ) with $R_{(340 / 380)}$ at the range of $0.7-1.25$ were included in this study.

Whole-cell patch-clamp recordings. Whole-cell recordings were performed on small diameter $(\leq 30 \mu \mathrm{m})$ DRG neurons with IgG-IC responsiveness identified by calcium imaging. The patch pipettes were pulled from borosilicate glass capillaries (Sutter Instrument; $1.2 \mathrm{~mm}$ outer diameter, $0.69 \mathrm{~mm}$ inner diameter) using a horizontal puller (model P97; Sutter Instrument). The resistance of the patch pipette was 3-4 M $\Omega$ when filled with an internal solution consisting of the following (in $\mathrm{mM}$ ): $120 \mathrm{~K}^{+}$-gluconate, $20 \mathrm{KCl}, 1 \mathrm{CaCl}_{2} \cdot 2 \mathrm{H}_{2} \mathrm{O}, 2 \mathrm{MgCl}_{2} \cdot 6 \mathrm{H}_{2} \mathrm{O}, 11 \mathrm{EGTA}, 10$ HEPES- $\mathrm{K}^{+}, 2$ MgATP, with $\mathrm{pH}$ adjusted to 7.2 using Tris-base and osmolarity adjusted to $290-300 \mathrm{mOsm}$ with sucrose. Series resistance was routinely compensated at $60-80 \%$. Whole-cell currents were sampled at $20 \mathrm{kHz}$ and filtered at $2 \mathrm{kHz}$ using a Multiclamp 700A amplifier and Pclamp 9 software package (Molecular Devices). Current-voltage $(I-V)$ plots were obtained at a holding potential of $-60 \mathrm{mV}$ with $750 \mathrm{~ms}$ voltage ramps at an interval of $2 \mathrm{~s}$ from -100 to $-10 \mathrm{mV}$ (Sun et al., 2006). A neuron was included only if the resting membrane potential was more negative than $-40 \mathrm{mV}$. Since the mean capacitance of the smallsize DRG neurons tested in each group was similar (data not shown), the peak amplitude of the currents rather than the current density (the ratio of peak amplitude to cell capacitance) was measured in this study for comparisons between groups. The neuron was considered capsaicin sensitive if an inward current was induced by the puff application of capsaicin $(1 \mu \mathrm{M})$ for $10 \mathrm{~s}$ at the end of whole-cell recordings. All the experiments were performed at room temperature $\left(20-22^{\circ} \mathrm{C}\right)$.

The DRG neurons were continuously perfused with the HEPES buffer. In some experiments, the $\mathrm{Ca}^{2+}$-free bath solution was applied in which the normal bath solution (HEPES buffer) was modified by the removal of $2 \mathrm{mM} \mathrm{CaCl}_{2}$, the addition of $0.1 \mathrm{~mm}$ EGTA, and an increase in the concentration of $\mathrm{MgCl}_{2}$ (4 mM) (Lu et al., 2006). The $\mathrm{Na}^{+}$-free bath solution was the same as the normal HEPES buffer, except that extracellular $\mathrm{Na}^{+}$ was replaced by $\mathrm{N}$-methyl-D-glucamine (NMDG). For delineation of $\mathrm{Ca}^{2+}$ permeability, the bath solution with $\mathrm{Ca}^{2+}$ as the sole cationic charge carrier $\left(\mathrm{Ca}^{2+}\right.$-only solution) was used as previously described (Poteser et al., 2011) and contained the following (in mM): 135 NMDG, 3 $\mathrm{CaCl}_{2}, 7 \mathrm{Ca}$-gluconate, $2 \mathrm{MgCl}_{2}, 10$ glucose, and 10 HEPES, at $\mathrm{pH}$ adjusted to 7.4 with methanesulfonic acid. The internal solutions with high and low $\mathrm{Ca}^{2+}$ buffer capacity were obtained by replacing $11 \mathrm{~mm}$ EGTA with $10 \mathrm{~mm}$ BAPTA and decreasing the concentration of $\mathrm{Ca}^{2+}$ and EGTA in the normal internal solution to 0.5 and $1 \mathrm{~mm}$, respectively (Qiu et al., 2010). All agents were dissolved in HEPES buffer and applied locally to the neuronal cell bodies through a micropipette with a tip diameter of $100 \mu \mathrm{m}$ and an 8-channel, pressure-controlled drug application system (AutoMate Scientific) (Ma et al., 2006). The interval between drug applications was 5-6 min. All chemicals were purchased from Sigma-Aldrich unless otherwise indicated.

Single-cell reverse-transcription PCR. The individual small-size DRG neurons were first examined for IgG-IC sensitivity by calcium imaging and then aspirated into a glass electrode with a tip diameter of $25-40 \mu \mathrm{m}$ and gently transferred into a PCR tube. For the negative control, a sample of the bath solution without any cell contents was used. The total RNA was extracted from individual DRG neuron using an RNeasy Plus Micro kit (Qiagen). The RNA was reverse transcribed using Superscript Reverse Transcriptase II (Invitrogen) according to the manufacturer's instructions. PCR amplification was then performed using a Titanium TaqPCR Kit (Clontech) with the primers as shown in Table 1. Beta III-tubulin was used as an internal control. The temperature cycles included an initial 4 -min denaturing step at $94^{\circ} \mathrm{C}$ followed by 40 cycles of 30 s denaturation 
Table 1. List of DNA primer sequences designed for single-cell RT-PCR

\begin{tabular}{|c|c|c|c|}
\hline Target gene & Primer sequence $5^{\prime}-3^{\prime}$ & $\begin{array}{l}\text { Product } \\
\text { length (bp) }\end{array}$ & $\begin{array}{l}\text { GenBank } \\
\text { no. }\end{array}$ \\
\hline CD64 & $\begin{array}{l}\text { AGTTGGAGCTATTTGGTCCCCAGTC } \\
\text { GCTAAGGTCCAGGGTCACCTGA }\end{array}$ & 300 & NM_001100836.1 \\
\hline $\operatorname{TRPC1}$ & $\begin{array}{l}\text { AGACGGCAGAACAGCTTGAAGGAGT } \\
\text { CACGGTGGCTTGGTCTGTGCTC }\end{array}$ & 141 & NM_053558.1 \\
\hline $\operatorname{TRPC3}$ & $\begin{array}{l}\text { TGATGAGGTGAACGAAGGTGAACTG } \\
\text { TGCCCACATTTGTGCCAGAGTCA }\end{array}$ & 206 & NM_021771.2 \\
\hline $\operatorname{TRPC4}$ & $\begin{array}{l}\text { AATTACTCGTCAACAGGCGGC } \\
\text { CACCACCACCTTCTCCGACTT }\end{array}$ & 203 & NM_080396.1 \\
\hline $\operatorname{TRPC5}$ & $\begin{array}{l}\text { AAGTTTCGAATTTGAGGAGCAGATG } \\
\text { AATCTCTGATGGCATCGCACA }\end{array}$ & 220 & NM_080898.2 \\
\hline $\operatorname{TRPC6}$ & $\begin{array}{l}\text { GCTCATCCAAACTGTCAGCA } \\
\text { CAGCATTCCAAAGTCAAGCA }\end{array}$ & 216 & NM_053559.1 \\
\hline TRPC7 & $\begin{array}{l}\text { ATGACGAGTTCTATGCCTACGACG } \\
\text { TTGTAGGCATTCATACGGGAGC }\end{array}$ & 226 & NM_001191691.2 \\
\hline$\beta 3$-tubulin & $\begin{array}{l}\text { GTCCGCCTGCCTCTTCGTCTC } \\
\text { TTGCCAGCACCACTCTGACCGAA }\end{array}$ & 335 & NM_139254.2 \\
\hline
\end{tabular}

at $94^{\circ} \mathrm{C}, 30 \mathrm{~s}$ annealing at $58^{\circ} \mathrm{C}$, and $30 \mathrm{~s}$ elongation at $68^{\circ} \mathrm{C}$. The reaction was completed with $5 \mathrm{~min}$ of final elongation at $68^{\circ} \mathrm{C}$. The PCR products were displayed on an ethidium bromide-stained $2 \%$ agarose gel.

Small interfering RNA transfection. DRG neurons were transfected with either a Stealth small interfering RNA (siRNA) or a Stealth RNAi negative control (Invitrogen) using the Lipofectamine 2000 transfection reagents (Invitrogen) according to the manufacturer's instructions. The target sequences of the Stealth siRNAs were 5' CCA CCC AGU UCA CAU GGA CAG AAA U 3' and 5' AUU UCU GUC CAU GUG AAC UGG GUG G 3' for TRPC3; and 5' CCA UGA CCA CUG GUA GAC AAC CAA U $3^{\prime}$ and $5^{\prime}$ AUU GGU UGU CUA CCA GUG GUC AUG G $3^{\prime}$ for the scrambled control of TRPC3 (Shirakawa et al., 2010). After $6 \mathrm{~h}$ treatment with siRNA, the medium was changed with DMEM containing $10 \%$ FCS, and the cells were incubated for $24-36 \mathrm{~h}$. The neurons without the addition of siRNA to the transfection reagents were used as an empty vector negative control.

Quantitative RT-PCR analysis. Total RNA was extracted from DRG neurons $48 \mathrm{~h}$ after transfection with scrambled or TRPC3 siRNA and then were reverse transcribed as described above. Following cDNA synthesis, qRT-PCR was performed using an iCycler single-color real-time PCR detection system (Bio-Rad) with iQ SYBR Green Supermix (BioRad). The sequences of primers for TRPC 3 and $\beta 3$-tubulin control are presented in Table 1 . The qPCR condition was $94^{\circ} \mathrm{C}$ for $4 \mathrm{~min}$, followed by 40 cycles of $94^{\circ} \mathrm{C}$ for $30 \mathrm{~s}, 58^{\circ} \mathrm{C}$ for $25 \mathrm{~s}$, and $72^{\circ} \mathrm{C}$ for $20 \mathrm{~s}$. After $5 \mathrm{~min}$ of final extension at $72^{\circ} \mathrm{C}$, a melt curve was generated. The identity of the PCR products was confirmed by automated determination of the melting temperature of the PCR products. The amplicons were displayed on an ethidium bromide-stained $2 \%$ agarose gel.

Immunofluorescent staining. Immunofluorescent labeling was performed on the dissociated rat DRG neurons to evaluate the expression level of TRPC3 receptors in DRG neurons under control and siRNAtreated conditions. Briefly, neurons were fixed by $2 \%$ paraformaldehyde for $20 \mathrm{~min}$ and incubated with blocking buffer (10\% normal horse serum and $0.2 \%$ Triton X-100 (Sigma-Aldrich) in PBS) for $1 \mathrm{~h}$, followed by incubation with the primary antibody (rabbit-anti-TRPC3, 1:400; Alomone Labs) at room temperature for $1 \mathrm{~h}$ and then with the secondary antibodies (Alexa Fluor 488-conjugated donkey-anti-rabbit, 1:500; Invitrogen) for $1 \mathrm{~h}$. Control staining was performed without primary antibody. The neurons were then washed in PBS and coverslipped with ProLong Gold antifade reagent with DAPI (Invitrogen) to stain nuclear profiles. The cells were visualized and the images were captured using a laser confocal microscopic imaging system (LMS 510; Carl Zeiss MicroImaging). The number of immunofluorescence-positive cells was counted using ImagePro Plus 5.0 (Media Cybernetics).

Data analysis. Data values are presented as mean \pm SEM. For a series of experiments in which IgG-IC was applied twice in normal conditions or under several chemical treatments, the second peak amplitude of cur-
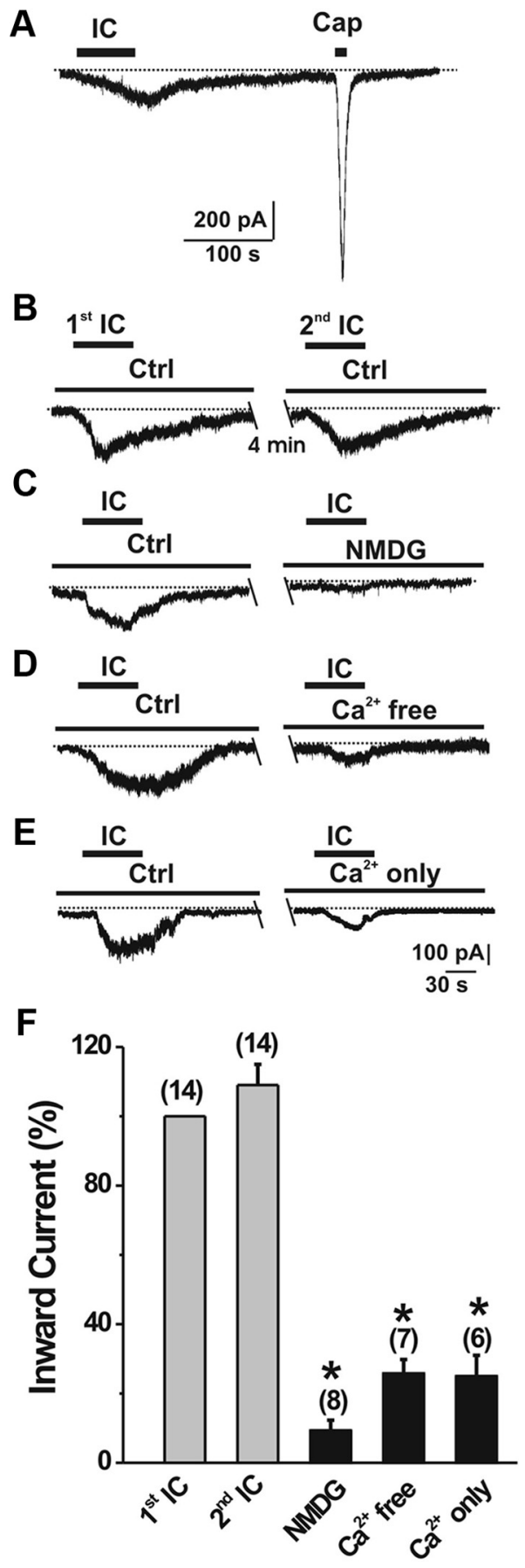

Figure 1. IgG-IC induced a cation current in small-size DRG neurons. The neurons were held at $-60 \mathrm{mV}$ in voltage-clamp mode. $A$, Typical traces of inward currents evoked by $\operatorname{lgG}-\mathrm{IC}(0.1$ $\mu \mathrm{g} / \mathrm{ml} ; 1 \mathrm{~min})$ and capsaicin $(1 \mu \mathrm{m} ; 10 \mathrm{~s}) . \boldsymbol{B}-\boldsymbol{E}$, Representative traces of $\mathrm{I}_{\mathrm{IC}}$ in a control HEPES bath solution $(\boldsymbol{B})$, an NMDG solution $(\boldsymbol{C})$, a $\mathrm{Ca}^{2+}$-free bath solution $(\boldsymbol{D})$, or a bath solution containing $\mathrm{Ca}^{2+}(10 \mathrm{~mm})$ as the only cation (E). $\boldsymbol{F}$, Summary of contributions of extracellular $\mathrm{Na}^{+}$and $\mathrm{Ca}^{2+}$ to the $\mathrm{I}_{\mathrm{C}}$. Replacement of extracellular $\mathrm{Na}^{+}$or $\mathrm{Ca}^{2+}$ significantly attenuated the $\mathrm{I}_{\mathrm{IC}} \mathrm{I}_{\mathrm{IC}}$ was decreased after switching to bath solution containing $\mathrm{Ca}^{2+}$ as the major cation. As a control, sequential application of IgG-IC at an interval of 5-6 min induced inward currents with the similar peak amplitudes. For each group, the first peak of the $\mathrm{I}_{\mathrm{I}} \mathrm{in}$ control HEPES bath solution was normalized as $100 \% .{ }^{*} p<0.001$ versus second IC. The number of cells tested is indicated in parentheses.

rents induced by IgG-IC was expressed as the percentage of the first response. Statistical analyses were performed using the SPSS 18.0 software (IBM). A Student's $t$ test was used for comparisons between two groups. Comparisons for more than three groups were carried out using 
A

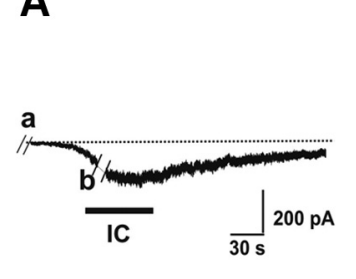

B

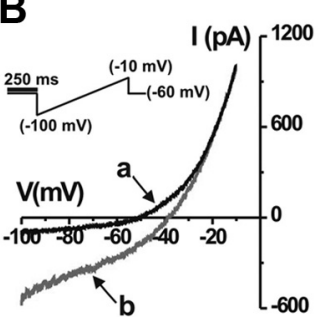

C

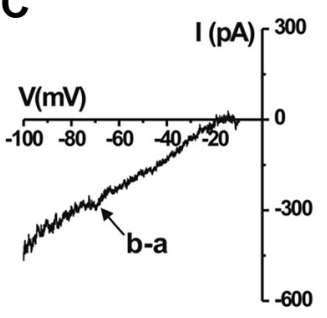

Figure 2. I-V relationship of the $\mathrm{I}_{\mathrm{I}} \cdot \boldsymbol{A}$, Application of $\mathrm{IgG}-\mathrm{IC}(0.1 \mu \mathrm{g} / \mathrm{ml} ; 1 \mathrm{~min})$ induced an inward current at a holding potential of $-60 \mathrm{mV}$. $\boldsymbol{B}$, Voltage ramps from $-100 \mathrm{mV}$ to $-10 \mathrm{mV}$ with a duration of $750 \mathrm{~ms}$ (inset) were applied every $2 \mathrm{~s}$ before (a) and during (b) the application of $\mathrm{IgG}-\mathrm{IC}(0.1 \mu \mathrm{g} / \mathrm{ml}) . C, I-V$ relationship of the $\mathrm{I}_{\mathrm{IC}}$ was obtained by subtracting a from $\mathrm{b}$. The $\mathrm{I}_{\mathrm{IC}}$ reversed near $-15 \mathrm{mV}$ for the sample cell.
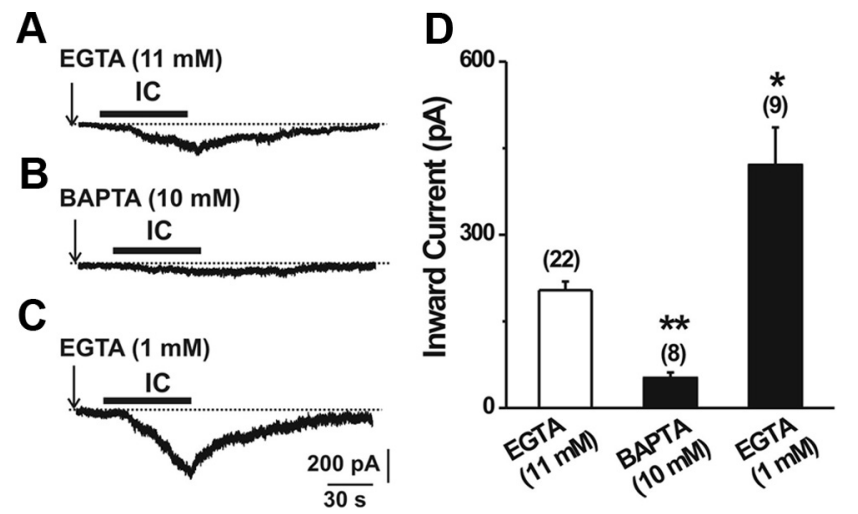

Figure 3. The $\mathrm{I}_{\mathrm{C}}$ was modulated by $\left[\mathrm{Ca}^{2+}\right]_{\mathrm{i}}$. $\boldsymbol{A}-\boldsymbol{C}$, Typical traces of the $\mathrm{I}_{\mathrm{C}}$ recorded at a holding potential of $-60 \mathrm{mV}$ using the internal solution containing $11 \mathrm{~mm} E G T A(A), 10 \mathrm{~mm}$ BAPTA (B), or $1 \mathrm{~mm}$ EGTA (C). D, Decreasing $\left[\mathrm{Ca}^{2+}\right]_{i}$ with fast $\mathrm{Ca}^{2+}$ chelator BAPTA (10 mm) significantly attenuated the $I_{1 C}$ whereas lowering the $\mathrm{Ca}^{2+}$ buffer capacity dramatically enhanced this current. Numbers in parentheses indicate the number of cells tested. ${ }^{*} p<0.05$ and ${ }^{* *} p<0.001$ versus $11 \mathrm{~mm}$ EGTA.

one-way ANOVA followed by Scheffés post hoc test. Comparisons of proportions were made using the $\chi^{2}$ test. Differences were considered statistically significant if $p<0.05$.

\section{Results}

\section{IgG immune complex induces a nonselective cationic} channel current

To determine the ionic mechanisms underlying the IgG-ICinduced depolarization, whole-cell voltage clamp recordings were performed on cultured DRG neurons before and after IgG-IC application. Bath application of IgG-IC $(0.1 \mu \mathrm{g} / \mathrm{ml})$ for 1 min induced an inward current $\left(\mathrm{I}_{\mathrm{IC}}\right)$ with a peak amplitude of $204.2 \pm 15.2 \mathrm{pA}(n=22)$ when the neurons were held at $-60 \mathrm{mV}$ (Fig. 1A). The $\mathrm{I}_{\mathrm{IC}}$ returned slowly to baseline within $3 \mathrm{~min}$ after washout of IgG-IC in all the neurons tested. Moreover, $72 \%$ of these neurons showed an inward current evoked by capsaicin (1 $\mu \mathrm{M}$; Fig. $1 A)$. When IgG-IC $(0.1 \mu \mathrm{g} / \mathrm{ml})$ was applied twice at an interval of 5-6 min, the peak of the second $\mathrm{I}_{\mathrm{IC}}$ was $193.8 \pm 19.1$ pA, which was not significantly different from the $206.8 \pm 24.6$ pA of the first (Fig. $1 B, F ; n=14 ; p>0.05$ ), suggesting that no desensitization occurred during repetitive applications of IgG-IC at the concentration of $0.1 \mu \mathrm{g} / \mathrm{ml}$.

To examine the contributions of extracellular $\mathrm{Na}^{+}$or $\mathrm{Ca}^{2+}$ to the $\mathrm{I}_{\mathrm{IC}}, \mathrm{Na}^{+}$and $\mathrm{Ca}^{2+}$ were, respectively, separately removed from the HEPES buffer. When extracellular $\mathrm{Na}^{+}$was replaced by NMDG, a large organic cation that cannot pass through cationic channels, the $\mathrm{I}_{\text {IC }}$ was decreased nearly to the baseline $(n=7)$ (Fig. $1 C, F)$. Removal of extracellular $\mathrm{Ca}^{2+}$ significantly reduced the

peak amplitude of the $\mathrm{I}_{\mathrm{IC}}(n=8)$ (Fig. $1 D, F)$, suggesting the $\mathrm{Ca}^{2+}$ dependence of the $\mathrm{I}_{\mathrm{IC}}$. In addition, switching the normal bath solution $\left(2 \mathrm{mM} \mathrm{Ca}^{2+}\right)$ to the solution containing $\mathrm{Ca}^{2+}(10 \mathrm{mM})$ as the sole cation $(n=6)$ (Fig. $1 E, F)$, abolished most, but not all, of the $\mathrm{I}_{\mathrm{IC}}$, indicating that the $\mathrm{I}_{\mathrm{IC}}$ is only partially carried by $\mathrm{Ca}^{2+}$. Therefore, the $\mathrm{I}_{\text {IC }}$ appears to be mediated by an NSCC, which is more likely carried by $\mathrm{Na}^{+}$and $\mathrm{Ca}^{2+}$.

To further estimate the $I-V$ relationship of the $\mathrm{I}_{\mathrm{IC}}$, a voltage ramp from -100 $\mathrm{mV}$ to $-10 \mathrm{mV}$ with a slope of $120 \mathrm{mV} / \mathrm{s}$ (Sun et al., 2006) was applied before and during IgG-IC application (Fig. $2 A, B$, inset), and the responding membrane current was recorded. The $\mathrm{I}_{\mathrm{IC}}$ for each neuron was obtained by subtracting the membrane current recorded in the absence of IgG-IC from that recorded in the presence of IgG-IC (Fig. 2C). To rule out the possible contaminations of action potentials, the membrane potential was only depolarized from $-100 \mathrm{mV}$ to $-10 \mathrm{mV}$ (Sun et al., 2006). Under physiological ionic conditions of $145 \mathrm{mM} \mathrm{Na}^{+}$externally and $140 \mathrm{mM} \mathrm{K}^{+}$in the internal solution, the $I-V$ relationship of the $\mathrm{I}_{\mathrm{IC}}$ for each neuron tested was linear over the voltage ranges tested, indicating a lack of voltage dependency (Fig. $2 C$ ). In addition, the mean reversal potential of the $\mathrm{I}_{\mathrm{IC}}$ was $-14.6 \pm 2.8 \mathrm{mV}(n=10)$ under physiological ionic conditions.

\section{The $\mathrm{I}_{\mathrm{IC}}$ is regulated by intracellular calcium}

Since the $\left[\mathrm{Ca}^{2+}\right]_{\mathrm{i}}$ was shown to increase after Fc $\gamma \mathrm{RI}$ cross-linking in DRG neurons (Andoh and Kuraishi, 2004; Qu et al., 2011a), we next examined whether the $\mathrm{I}_{\mathrm{IC}}$ is modulated by intracellular calcium. BAPTA, the fast $\mathrm{Ca}^{2+}$ chelator, buffers $\mathrm{Ca}^{2+}$ ions $\sim 200$ fold more rapidly, though BAPTA and EGTA have similar $K_{\mathrm{D}} \mathrm{s}$ for $\mathrm{Ca}^{2+}$ binding. Thus, BAPTA chelates $\left[\mathrm{Ca}^{2+}\right]_{\mathrm{i}}$ more effectively at the same time and spatial scales near $\mathrm{Ca}^{2+}$ entry points (Naraghi, 1997; Neher, 1998). When 11 mM EGTA in the internal solution was replaced with $10 \mathrm{~mm}$ BAPTA, the peak of the $\mathrm{I}_{\mathrm{IC}}$ was significantly decreased from $204.2 \pm 15.2 \mathrm{pA}(n=22)$ (Fig. $3 A)$ in EGTA-buffered internal solution to $53.1 \pm 9.5 \mathrm{pA}(n=8)$ (Fig. $3 B, D)$. By contrast, when intracellular $\mathrm{Ca}^{2+}$ buffering capacity was lowered by reducing the concentration of EGTA from 11 to 1 $\mathrm{mM}$ in the internal solution, the $\mathrm{I}_{\mathrm{IC}}$ was dramatically increased to 420.8. $\pm 65.2 \mathrm{pA}(n=9)$ (Fig. $3 C, D)$, suggesting that the $\mathrm{I}_{\mathrm{IC}}$ is regulated or sensitized by $\left[\mathrm{Ca}^{2+}\right]_{\mathrm{i}}$.

\section{TRPC channels contribute to the $\mathrm{I}_{\mathrm{IC}}$}

When considering a potential molecular target for the IgG-IC, we realized that all the properties of the $\mathrm{I}_{\mathrm{IC}}$ resembled the TRPC current, one major type of $\mathrm{Ca}^{2+}$-permeable NSCCs. These included nonselectivity for cations, lack of voltage gating, and intracellular $\mathrm{Ca}^{2+}$ dependence (Clapham et al., 2005). More important, a recent study revealed that TRPC3/6/7 channel subtypes were involved in IgE-IC-triggered signaling in mast cells (Sanchez-Miranda et al., 2010). Therefore, we tested whether the $\mathrm{I}_{\mathrm{IC}}$ was mediated by TRPC channels in DRG neurons. To test this possibility, single-cell RT-PCR (scRT-PCR) analysis was used to determine the coexpression pattern of Fc $\gamma$ RI (CD64) and TRPC channel subtypes in individual DRG neurons with IgG-IC responsiveness established by calcium imaging. Since TRPC2 is not expressed in rat DRG neurons (Kress et al., 2008), it was excluded from the present study. Consistent with previous studies (Kress et 
al., 2008), TRPC5 and TRPC7 were not detected in DRG neurons after $1 \mathrm{~d}$ in culture. Among all the neurons tested, the Fc $\gamma$ RI-positive population also expressed TRPC3 $(n=10)$ (Fig. $4 A$ ). In contrast, the coexpression of Fc $\gamma$ RI with other TRPC subtypes was not observed consistently across the neurons tested (Fig. 4A). These results provide additional evidence that TRPC3 is likely a molecular candidate for the nature of the $\mathrm{I}_{\mathrm{IC}}$. Therefore, we next asked whether the $\mathrm{I}_{\mathrm{IC}}$ is attenuated by pharmacological or genetic knockdown of TRPC3 channels. Bath application of ruthenium red $(10 \mu \mathrm{M})$, an inhibitor of several TRP channels (Clapham et al., 2005), almost completely blocked the $\mathrm{I}_{\mathrm{IC}}(n=7)$ (Fig. $4 B, F$ ). When the neurons were pretreated with $10 \mu \mathrm{M}$ BTP2, a known general TRPC blocker at this dose in native cells (Miyano et al., 2010), the $\mathrm{I}_{\mathrm{IC}}$ was also significantly attenuated $(n=7)$ (Fig. $4 C, F)$. Furthermore, pyrazole-3 $(10 \mu \mathrm{M})$, a selective TRPC3 antagonist (Kiyonaka et al., 2009; Shirakawa et al., 2010), significantly reduced the peak amplitude of the $\mathrm{I}_{\mathrm{IC}}$ $(n=7)$ (Fig. 4D, F). Since TRPAl is also a $\mathrm{Ca}^{2+}$-modulated NSCC (Doerner et al., 2007), we next tested whether TRPA1 contributes to the $\mathrm{I}_{\mathrm{IC}}$. Treatment with a selective TRPA1 antagonist, HC-030031 $(100 \mu \mathrm{M})$, had no significant effect on the $\mathrm{I}_{\text {IC }}(n=5)$ (Fig. $\left.4 E, F\right)$.

To further probe the role of TRPC3 in the $\mathrm{I}_{\mathrm{IC}}$, TRPC3 was knocked down with a specific siRNA in DRG neurons. The significant reduction of $\mathrm{mRNA}$ and protein expression of TRPC3 after siRNA transfection was confirmed by both RT-PCR (Fig. 5A) and immunofluorescence staining (Fig. $5 B$ ), respectively. The expression of TRPC3 was similar in both vector-negative control and scrambled siRNA control. The percentage of TRPC3-immunopositive neurons was significantly lower in the siRNA-treated samples $(13.7 \%$, or $20 / 146)$ as compared to those treated with scrambled siRNA $(43.6 \%$, or $51 / 117)\left(p<0.001, \chi^{2}\right.$ test $)$. Calcium imaging indicated that IgG-IC-evoked $\mathrm{Ca}^{2+}$ responses were significantly suppressed in TRPC3 siRNA-transfected cells $(n=18)$, whereas transfection of a scrambled siRNA $(n=18)$ did not substantially change the IgG-IC effect, as compared to the vector control (Fig. $5 C-E)$. In addition, specific knockdown of TRPC3 $(n=11)$ significantly attenuated the peak amplitude of the $\mathrm{I}_{\mathrm{IC}}$, whereas the scrambled siRNA $(n=10)$ had no such effect (Fig. $5 F-H)$. These findings indicate that TRPC3 is a likely key candidate channel responsible for mediating the $\mathrm{I}_{\mathrm{IC}}$.

Fc $\gamma$ RI couples to TRPC3 through the spleen tyrosine kinasephospholipase $\mathrm{C}$-inositol trisphosphate signaling pathway Activation of Fc $\gamma$ RI by IgG-IC is known to stimulate the spleen tyrosine kinase (Syk)-phospholipase C (PLC)-inositol trisphosphate $\left(\mathrm{IP}_{3}\right)$ signaling pathway in macrophages and monocytic cell lines (van de Winkel et al., 1990; Liao et al., 1992; Kiener et al., 1993; Bonilla et al., 2000; Nimmerjahn and Ravetch, 2007).
Moreover, TRPC channels are activated or modulated by PLCcoupled receptors (Montell, 2008), making them likely downstream targets of IgG-IC. Thus, we next examined whether Fc $\gamma$ RI can couple to TRPC channels through the Syk-PLC-IP 3 signaling pathway. Pretreatment with Syk inhibitor OXSI-2 $(10 \mu \mathrm{M} ; n=9)$ (Fig. $6 A, E)$ or PLC inhibitor neomycin $(100 \mu \mathrm{M} ; n=11)$ for 4 min almost abolished the $\mathrm{I}_{\mathrm{IC}}(n=9)$ (Fig. $\left.6 B, E\right)$, suggesting that the $\mathrm{I}_{\mathrm{IC}}$ was mediated through Syk and PLC. TRPC3 was shown to be directly activated by diacylglycerol (DAG) (Zitt et al., 1997; Trebak et al., 2003b). However, the IIC was unlikely to be mediated by DAG since the membrane-permeable DAG analog OAG $(100 \mu \mathrm{M})$ alone failed to induce an inward current in all IgG-IC responsive neurons tested $(n=5)$ (Fig. $6 C, E)$. In addition to DAG, TRPC3 channels can interact with $\mathrm{IP}_{3}$ receptors or can be activated through $\mathrm{Ca}^{2+}$ release from internal stores (Kiselyov et al., 1998; Ma et al., 2000). When the neurons was perfused with membrane-permeate $\mathrm{IP}_{3}$ receptor antagonist 2-APB $(100 \mu \mathrm{M})$ (Ma et al., 2000; Qiu et al., 2010), the I IC was significantly reduced $(n=8)$ (Fig. $6 D, E)$. Although 2 -APB is also considered as a potent blocker of TRPC channels, it acts on extracellular but not intracellular sites of TRPC channels (Trebak et al., 2002; Xu et al., 2005; Raybould et al., 2007). Thus, to further determine whether 

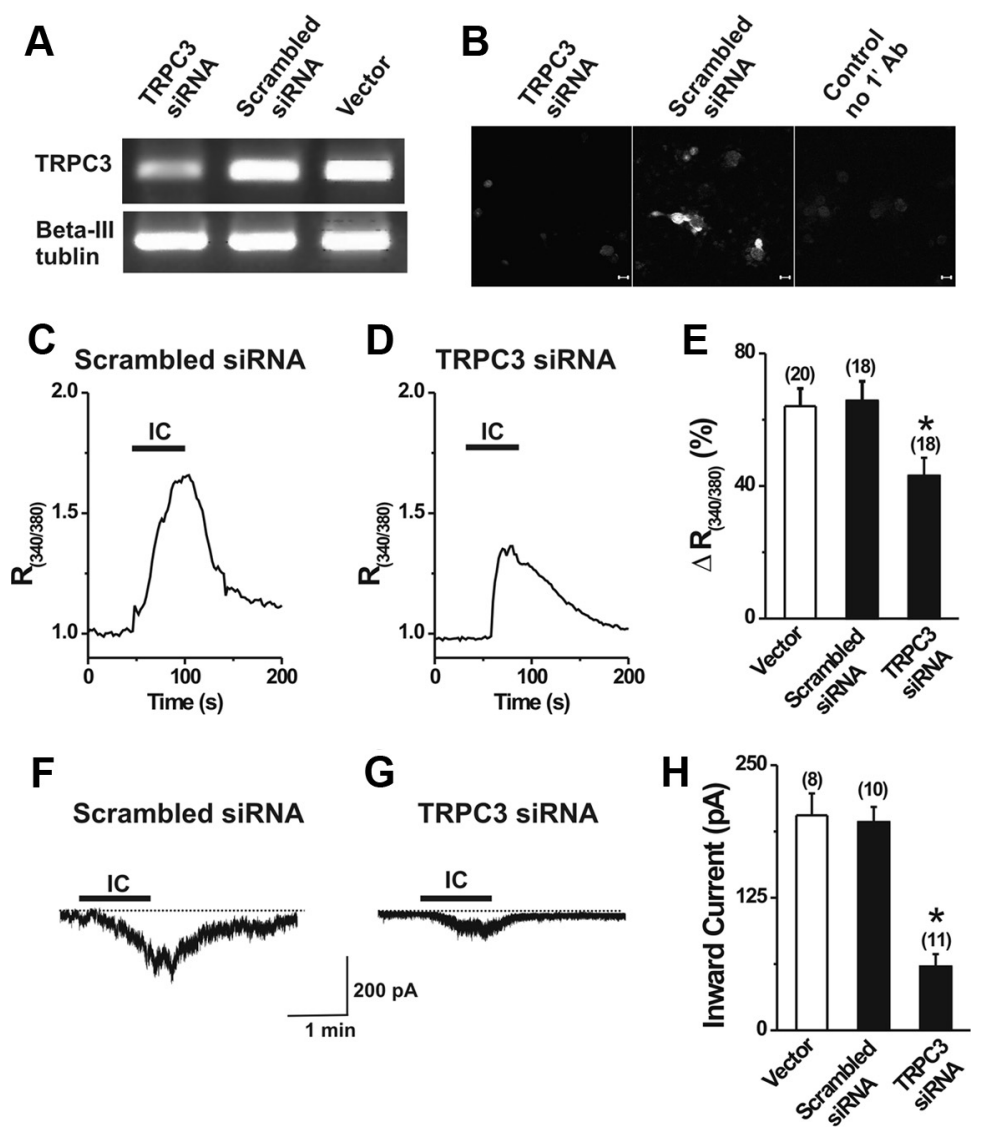

Figure 5. $\quad \boldsymbol{A}, \boldsymbol{B}$, Knockdown of TRPC3 with a specific siRNA reduced the lgG-IC-induced response. RT-PCR $(\boldsymbol{A})$ and immunofluorescent staining $(\boldsymbol{B})$ showed that TRPC3 siRNA but not scrambled siRNA knocked down the expression of TRPC 3 in DRG neurons. The control staining of TRPC3 ( $\boldsymbol{B}$, right) was performed without primary antibody $\left(1^{\prime} A b\right) . C, D$, Representative $C^{2}{ }^{2+}$ responses induced by IgG-IC in DRG neurons transfected with a scrambled siRNA (C) or TRPC3 siRNA (D). $\boldsymbol{E}$, IgG-IC-induced $\mathrm{Ca}^{2+}$ response $\left[R_{(340 / 380)}\right]$ was significantly decreased in TRPC3 siRNA-transfected cells, as compared to vector or scrambled siRNA-transfected cells. There were significant differences in lgG-IC-induced $\mathrm{Ca}^{2+}$ responses between vector and scrambled siRNA-transfected cells. ${ }^{*} p<0.05$ versus vector or scrambled siRNA. $\boldsymbol{F}, \boldsymbol{G}$, Typical traces of The $\mathrm{I}_{\mathrm{IC}}$ recorded from DRG neurons transfected with scrambled siRNA $(\boldsymbol{F})$ and TRPC3 siRNA $(\boldsymbol{G})$, respectively. $\boldsymbol{H}$, The $\mathrm{I}_{\mathrm{I}}$ was significantly attenuated by the knockdown of TRPC3 with a specific siRNA whereas the scrambled siRNA had no effect on this current. The neurons were held at $-60 \mathrm{mV} .{ }^{*} p<0.001$ versus vector or scrambled siRNA. Cell numbers are indicated in parentheses.

the inhibitory effect of $2-\mathrm{APB}$ on the $\mathrm{I}_{\mathrm{IC}}$ was attributable to a direct blockade of TRPC channels or $\mathrm{IP}_{3}$ receptors, 2-APB (100 $\mu \mathrm{M})$ was added to the internal solution. Intracellular 2-APB still produced suppression of the $\mathrm{I}_{\mathrm{IC}}(33.8 \pm 6.9 \mathrm{pA}, n=9)$ (Fig. $6 F, H)$, similar to that when 2-APB was applied to the bath solution $(28.5 \pm 7.5 \mathrm{pA}, n=8)$. The result suggests that 2 -APB mainly acts on $\mathrm{IP}_{3}$ receptors to block the IgG-IC response. Similarly, the $\mathrm{I}_{\text {IC }}$ was also inhibited $(n=6)$ (Fig. $\left.6 G, H\right)$ when another $\mathrm{IP}_{3}$ receptor antagonist, heparin $(100 \mu \mathrm{g} / \mathrm{ml})$ (Li et al., 1999), was dialyzed into the cells. Thus, the $\mathrm{I}_{\mathrm{IC}}$ might be activated through a store-operated mechanism.

\section{Discussion}

In this study, we have demonstrated for the first time that IgG-IC elicits a nonselective cation current in DRG neurons via neuronal Fc $\gamma$ RI. Moreover, TRPC3 appears to be a key downstream transduction channel mediating the $\mathrm{I}_{\mathrm{IC}}$. In addition, the Syk- PLC- $\mathrm{IP}_{3}$ signaling pathway is likely required for coupling Fc $\gamma \mathrm{RI}$ to TRPC3 in DRG neurons.

\section{TRPC 3 contributes to the $\mathrm{I}_{\mathrm{IC}}$ in DRG neurons}

Our present study provided three lines of original evidence to support the hypothesis that IgG-IC induced a cation current mainly flowing through TRPC3 channels in DRG neurons, therefore contributing to IgG-IC-induced neuronal excitation. First, bath application of IgG-IC elicited an NSCC, which was carried by $\mathrm{Na}^{+}$and $\mathrm{Ca}^{2+}$ with a reversal potential of approximately $-15 \mathrm{mV}$ under physiological conditions. Moreover, the $\mathrm{I}_{\mathrm{IC}}$ was regulated or sensitized by intracellular $\mathrm{Ca}^{2+}$. These features of the $\mathrm{I}_{\mathrm{IC}}$ are similar to those of TRPC3 channels in vitro (Wu et al., 2010). Accordingly, a recent study revealed that TRPC3/6/7 channel subtypes were involved in FceRI signaling in mast cells (Sanchez-Miranda et al., 2010). Thus, it is likely that TRPC channels are a potential downstream target of the IgG-IC in the DRG neurons. Second, scRT-PCR results demonstrated a consistent coexpression of Fc $\gamma$ RI (CD64) with TRPC3 mRNA in the same DRG neurons, suggesting that Fc $\gamma \mathrm{RI}$ is more likely associated with the TRPC3, either directly or indirectly. Third, the $\mathrm{I}_{\mathrm{IC}}$ was blocked by the general TRPC channel inhibitors RR and BTP2 and by the selective TRPC3 antagonist pyrazole-3. Particularly, a knockdown of TRPC3 significantly decreased the $\mathrm{I}_{\mathrm{IC}}$ and IgG-IC-induced $\left[\mathrm{Ca}^{2+}\right]_{\mathrm{i}}$ elevations.

We showed that the IgG-IC-induced $\mathrm{Ca}^{2+}$ response was less suppressed after transfection of TRPC3 siRNA, as compared to the peak of $\mathrm{I}_{\mathrm{IC}}(35 \%$ vs $69 \%)$, perhaps because $\mathrm{Ca}^{2+}$ release from internal stores is a major source for IgG-ICinduced $\mathrm{Ca}^{2+}$ response, in addition to the $\mathrm{Ca}^{2+}$ entry from extracellular space, such as through TRPC3 (Qu et al., 2011a). By contrast, the $\mathrm{I}_{\mathrm{IC}}$ is likely to be mainly mediated by TRPC3 channels. However, a small residual $\mathrm{I}_{\mathrm{IC}}$ was still detected after pharmacological inhibition or gene knockdown of TRPC3 channels, which might indicate a contribution of other channels, especially in different neuronal types. Among the candidate NSCCs, TRPA1 is highly expressed in DRG neurons and may also function as a $\mathrm{Ca}^{2+}$-gated NSCC (Doerner et al., 2007). However, the TRPA1-selective antagonist HC030031 did not affect the peak of the $\mathrm{I}_{\mathrm{IC}}$, suggesting that TRPA1 does not contribute to the $\mathrm{I}_{\mathrm{IC}}$ in these DRG neurons. In addition, it is unlikely that the $\mathrm{I}_{\mathrm{IC}}$ is mediated by TRPV1 for the following reasons: first, the $\mathrm{I}_{\text {IC }}$ can still be observed in a subset of capsaicin-insensitive neurons although the majority of IgG-IC responsive neurons (72\%) are sensitive to capsaicin; second, TRPV1 is normally activated by 2-APB (Hu et al., 2004; Colton and Zhu, 2007) whereas the $\mathrm{I}_{\mathrm{IC}}$ was blocked by 2-APB.

A potential discrepancy between the characteristics of the $\mathrm{I}_{\mathrm{IC}}$ and the TRPC3 current in expressing cell lines (Zitt et al., 1997; Poteser et al., 2011) is the lack of outward rectification in the $\mathrm{I}_{\mathrm{IC}}$ recorded in DRG neurons. This difference is likely due to a relatively narrow voltage range $(-100$ to $-10 \mathrm{mV}$, to avoid action potential contamination) used in this study. It is also possible that the $I-V$ relationship of TRPC 3 in native cells is different from that in the expressing cell lines (Li et al., 1999). The endogenous $\mathrm{I}_{\text {IC }}$ in 
DRG neurons is only partially carried by $\mathrm{Ca}^{2+}$, which is slightly different from the characteristics of TRPC 3 in expressing cell lines while consistent with that in pontine neurons (Li et al., 1999).

\section{Syk-PLC-IP ${ }_{3}$ signaling pathway is} required for $\mathrm{Fc} \gamma \mathrm{RI}$ coupling to TRPC3 Another important finding of this study is that Fc $\gamma$ RI and TRPC3 are functionally coupled to each other through the SykPLC- $\mathrm{IP}_{3}$ signaling pathway. In immune cells, the activation of Fc $\gamma$ RI by IgG-IC results in the phosphorylation of Syk, a non-receptor tyrosine kinase (Kiener et al., 1993; Indik et al., 1995). Activated Syk stimulates PLC, which hydrolyzes the membrane phospholipid phosphatidylinositol 4,5-bisphosphate to produce $\mathrm{IP}_{3}$ and DAG (van de Winkel et al., 1990; Liao et al., 1992; Kiener et al., 1993; Bonilla et al., 2000; Nimmerjahn and Ravetch, 2007). In addition, TRPC 3 has been shown to be activated or modulated by PLC signaling (Montell, 2008). Thus, it is likely that Fc $\gamma$ RI couples to TRPC3 through the Syk-PLC- $\mathrm{IP}_{3}$ signaling pathway following IgG-IC treatment. Consistent with this hypothesis, we found, by use of pharmacological inhibitors, that the $\mathrm{I}_{\mathrm{IC}}$ observed in DRG neurons is mediated by an intracellular signaling pathway involving Syk, PLC, and the $\mathrm{IP}_{3}$ receptors. We showed that bath application of OXSI-2, the potent Syk inhibitor (Lai et al., 2003), inhibited the $\mathrm{I}_{\mathrm{IC}}$. Since the PLC blocker U7322 itself was shown to cause an irreversible increase in $\left[\mathrm{Ca}^{2+}\right]_{\mathrm{i}}$ in DRG neurons, neomycin was used in this study instead (Bonnington and McNaughton, 2003). The $I_{\text {IC }}$ was also blocked by neomycin. In addition, the inclusion of $2-\mathrm{APB}$ or heparin to the pipette solution produced suppression of the $\mathrm{I}_{\mathrm{IC}}$. Furthermore, the blocking effects of 2-APB were more likely due to the intracellular blockade of the $\mathrm{IP}_{3}$ receptors rather than the direct inhibition of TRPC channels since the binding site of 2-APB is normally located extracellularly for the inhibition of TRPC channels (Trebak et al., 2002; Xu et al., 2005; Raybould et al., 2007).

In most of the early studies using TRPC3-expressing cell lines, TRPC3 has been proposed to function as a receptoroperated cation channel that can be activated by $D A G$ but not through the production of $\mathrm{IP}_{3}$ or via a store-operated mechanism (Hofmann et al., 1999; Trebak et al., 2003a). However, some studies indicated that TRPC3 behaves as an SOC that interacts with $\mathrm{IP}_{3}$ receptors and is activated through the release of $\mathrm{Ca}^{2+}$ from

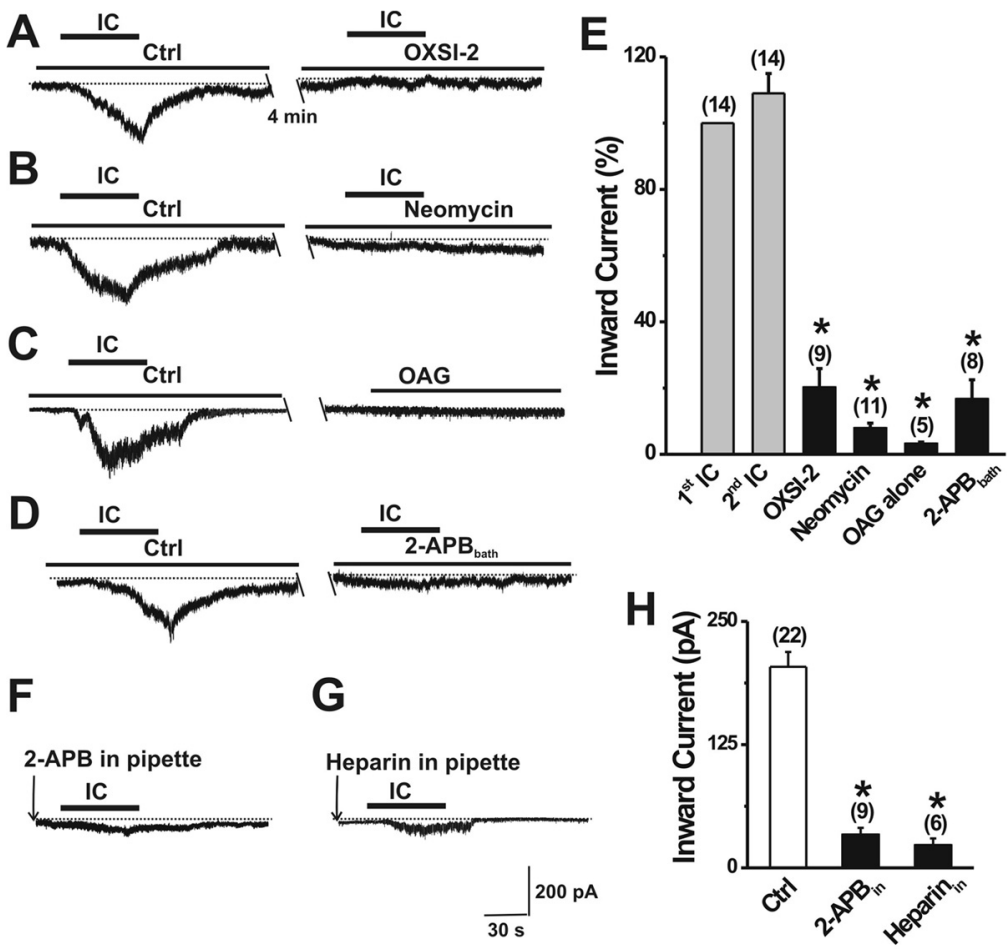

Figure 6. The Syk-PLC-IP 3 signaling pathway was required for functional coupling of $\mathrm{Fc} \gamma \mathrm{RI}$ to TRPC3. $\boldsymbol{A}-\boldsymbol{D}$, Typical traces of the $\mathrm{I}_{\mathrm{C}}$ recorded at a holding potential of $-60 \mathrm{mV}$ in the presence of Syk inhibitor OXSI-2 (10 $\left.\mu \mathrm{M} ; A\right)$, PLC inhibitor neomycin (10 $\mu \mathrm{m} ; \boldsymbol{B})$, DAG analog OAG alone (100 $\mu \mathrm{m} ; \boldsymbol{C})$, or IP $\mathrm{P}_{3}$ receptor blocker 2-APB $(100 \mu \mathrm{m} ; \boldsymbol{D})$. $\boldsymbol{E}$, Treatment with OXSI-2, neomycin and 2-APB substantially reduced the peak amplitude of the $\mathrm{I}_{\mathrm{I}}$. Bath application of OAG alone failed to induce an inward current in IgG-IC-responsive neurons. For each group, the second peak amplitude of the $\mathrm{I}_{\mathrm{IC}}$ was expressed as the percentage of the first response. ${ }^{*} p<0.001$ versus second IC. $\boldsymbol{F}, \mathbf{G}$, Inclusion of 2-APB $(100 \mu \mathrm{m} ; \boldsymbol{F})$ or heparin $(100 \mu \mathrm{g} / \mathrm{ml} ; \boldsymbol{G})$ in the patch pipette prevented the $\mathrm{I}_{\mathrm{I} C} \cdot \boldsymbol{H}$, Summary of the inhibitory effects of internal $2-\mathrm{APB}$ and heparin on the $\mathrm{I}_{\mathrm{IC}} \cdot{ }^{*} p<0.001$ versus control. The number of cells tested is shown above each bar.

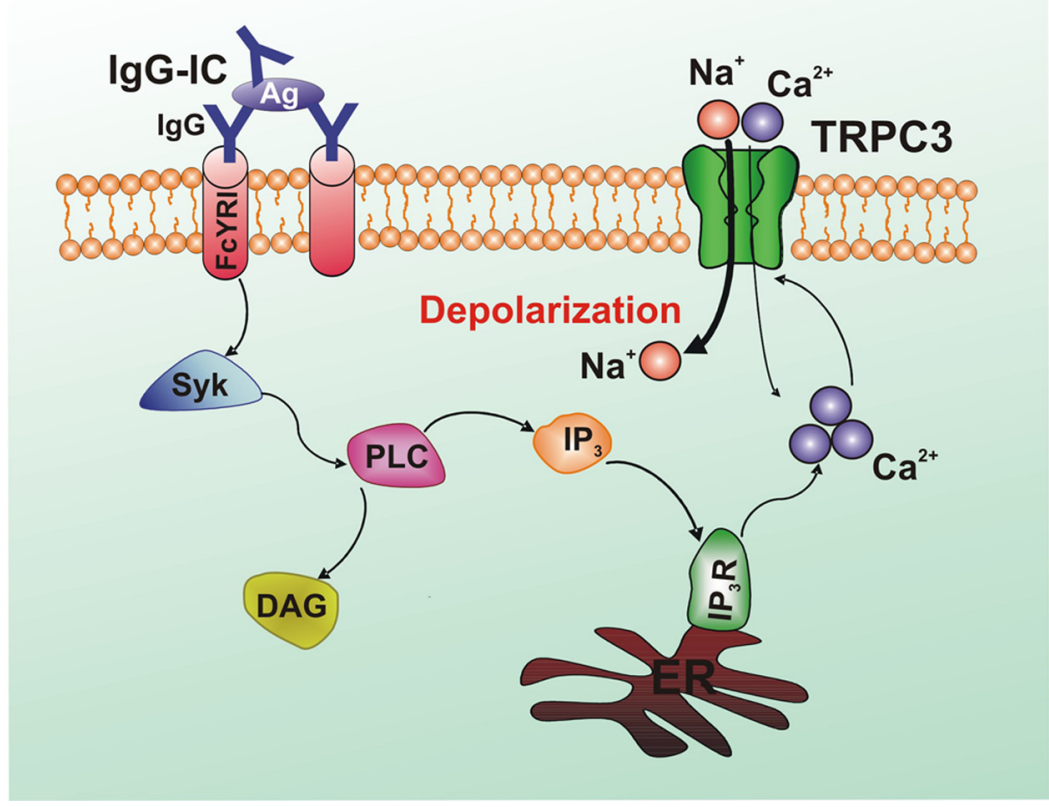

Figure 7. Schematic illustration demonstrating signaling pathways involved in IgG-IC-induced excitation in rat DRG neurons. IgG-IC binding to its receptor ( $\mathrm{Fc}(\mathrm{RI})$ stimulates Syk, which leads to the activation of PLC. PLC subsequently hydrolyzes the phosphatidylinositol 4,5-bisphosphate to generate $D A G$ and $\mathbb{I}_{3} . \mathbb{I}_{3}$ binds to $\mathbb{I P}_{3}$ receptors in endoplasmic reticulum to induce $\mathrm{Ca}^{2+}$ release from internal stores, which in turn enhances or sensitizes TRPC3 activity, resulting in further $\mathrm{Ca}^{2+}$ influx and membrane depolarization. However, DAG is unlikely involved in $\mathrm{Fc} \gamma \mathrm{Rl}$-trigged signaling. All these signaling events consequently increase the excitability of DRG neurons. 
internal stores (Kiselyov et al., 1998; Ma et al., 2000; Kaznacheyeva et al., 2007; Kim et al., 2009). Here we showed that the IIC was blocked by the $\mathrm{IP}_{3}$ receptor antagonist 2- $\mathrm{APB}$ and heparin and by the SOC blocker BTP2 but was not affected by the DAG analog $\mathrm{OAG}$, indicating that the $\mathrm{I}_{\mathrm{IC}}$ is more likely activated through a store-operated mechanism in the same way as TRPC3 (Ma et al., 2000; He et al., 2005), consistent with a previous study (Floto et al., 1997). We also showed that lowering the intracellular calcium buffering power potentiated, whereas enhancing the calcium buffering capacity of the internal solution attenuated, the $\mathrm{I}_{\mathrm{IC}}$, suggesting that $\mathrm{I}_{\mathrm{IC}}$ is modulated by $\left[\mathrm{Ca}^{2+}\right]_{\mathrm{i}}$. Taken together, these findings indicate that IgG-IC activates TRPC 3 in DRG neurons through a signaling pathway that involves Syk, PLC, $\mathrm{IP}_{3}$ receptor, and intracellular $\mathrm{Ca}^{2+}$ (Fig. 7). These results suggest that TRPC3 likely behaves as an SOC in Fc $\gamma$ RI-triggered signaling in DRG neurons.

\section{Functional implications}

IgG-IC plays a critical role in the pathogenesis of pain (Verri et al., 2008; Ma et al., 2009). A predominant immune cell-centric view is that IgG-IC may induce pain and hyperalgesia via the activation of certain immune cells and the release of proinflammatory cytokines (Verri et al., 2007, 2008; Pinto et al., 2010). Moreover, Fc $\gamma$ Rs, expressed on immune cells, appear to play an important role in this process (Nimmerjahn and Ravetch, 2006, 2008). However, recent studies revealed that IgG-IC directly excited primary sensory neurons though neuronal Fc $\gamma$ RI (Andoh and Kuraishi, 2004; Qu et al., 2011a), which may cause pain sensation. In addition, activation of neuronal Fc $\gamma \mathrm{RI}$ triggered the release of certain proinflammatory neurotransmitters from DRG neurons, such as substance P (Andoh and Kuraishi, 2004). These mediators may further induce neurogenic inflammation and may, in turn, excite DRG neurons via their own receptors expressed on DRG neurons through a paracrine or an autocrine pathway (van Rossum et al., 1997; Tang et al., 2007). This study extends previous findings by providing evidence that neuronal $\mathrm{Fc} \gamma \mathrm{RI}$ triggers an NSCC-TRPC3, which may contribute to the IgG-IC-induced excitation of DRG neurons.

However, these neuropathic mechanisms become critical only under certain pathological conditions. In the normal nervous system, the presence of blood-nerve/brain-barriers and glial cells protects the surface of a primary sensory neuron against large molecules such as IgG-IC and IgG. By contrast, under pathological conditions that disrupt these barriers and demyelinate the peripheral and central neurons (Abbott et al., 2003; SastreGarriga and Montalban, 2003; Hu and Lucchinetti, 2009), the neuronal surface is more readily exposed to IgG-IC present in the serum or surrounding tissues. Thus, IgG-IC can bind to neuronal $\mathrm{Fc} \gamma \mathrm{RI}$ and directly activate the primary sensory neurons, therefore possibly inducing pain, hyperalgesia, and allodynia. However, the actual behavioral consequences of IgG-IC activation of TRPC3 channels in nociceptors remain to be determined, and nothing is known about the functions of the much more widely expressed Fc $\gamma$ RI in the larger DRG neurons (Qu et al., 2011a) that are unlikely to be nociceptive.

In summary, this study reveals a novel mechanism whereby IgG-IC induces the activation of primary sensory neurons via the functional coupling between Fc $\gamma$ RI and TRPC3 through the Syk$\mathrm{PLC}-\mathrm{IP}_{3}$ signaling pathway. These findings might serve as a basis for the development of new therapeutic strategies for the treatment of pain related to IgG-IC-mediated immune diseases.

\section{References}

Abbott NJ, Mendonça LL, Dolman DE (2003) The blood-brain barrier in systemic lupus erythematosus. Lupus 12:908-915.

Andoh T, Kuraishi Y (2004) Direct action of immunoglobulin G on primary sensory neurons through Fc gamma receptor I. FASEB J 18:182-184.

Bonilla FA, Fujita RM, Pivniouk VI, Chan AC, Geha RS (2000) Adapter proteins SLP-76 and BLNK both are expressed by murine macrophages and are linked to signaling via Fcgamma receptors I and II/III. Proc Natl Acad Sci U S A 97:1725-1730.

Bonnington JK, McNaughton PA (2003) Signalling pathways involved in the sensitisation of mouse nociceptive neurones by nerve growth factor. J Physiol 551:433-446.

Clapham DE, Julius D, Montell C, Schultz G (2005) International Union of Pharmacology, XLIX: nomenclature and structure-function relationships of transient receptor potential channels. Pharmacol Rev 57:427-450.

Colton CK, Zhu MX (2007) 2-Aminoethoxydiphenyl borate as a common activator of TRPV1, TRPV2, and TRPV3 channels. Handb Exp Pharma$\operatorname{col}(179): 173-187$.

Doerner JF, Gisselmann G, Hatt H, Wetzel CH (2007) Transient receptor potential channel A1 is directly gated by calcium ions. J Biol Chem 282:13180-13189.

Floto RA, Somasundaram B, Allen JM, Mahaut-Smith MP (1997) Fcgamma receptor I activation triggers a novel $\mathrm{Ca} 2+$-activated current selective for monovalent cations in the human monocytic cell line, U937. J Biol Chem 272:4753-4758.

Grynkiewicz G, Poenie M, Tsien RY (1985) A new generation of Ca2+ indicators with greatly improved fluorescence properties. J Biol Chem 260:3440-3450.

He LP, Hewavitharana T, Soboloff J, Spassova MA, Gill DL (2005) A functional link between store-operated and TRPC channels revealed by the 3,5-bis(trifluoromethyl)pyrazole derivative, BTP2. J Biol Chem 280:10997-11006.

Hofmann T, Obukhov AG, Schaefer M, Harteneck C, Gudermann T, Schultz G (1999) Direct activation of human TRPC6 and TRPC3 channels by diacylglycerol. Nature 397:259-263.

Hu HZ, Gu Q, Wang C, Colton CK, Tang J, Kinoshita-Kawada M, Lee LY, Wood JD, Zhu MX (2004) 2-aminoethoxydiphenyl borate is a common activator of TRPV1, TRPV2, and TRPV3. J Biol Chem 279:35741-35748.

Hu W, Lucchinetti CF (2009) The pathological spectrum of CNS inflammatory demyelinating diseases. Semin Immunopathol 31:439-453.

Indik ZK, Park JG, Hunter S, Schreiber AD (1995) The molecular dissection of Fc gamma receptor mediated phagocytosis. Blood 86:4389-4399.

Kaida K, Ariga T, Yu RK (2009) Antiganglioside antibodies and their pathophysiological effects on Guillain-Barre syndrome and related disorders-a review. Glycobiology 19:676-692.

Kaznacheyeva E, Glushankova L, Bugaj V, Zimina O, Skopin A, Alexeenko V, Tsiokas L, Bezprozvanny I, Mozhayeva GN (2007) Suppression of TRPC3 leads to disappearance of store-operated channels and formation of a new type of store-independent channels in A431 cells. J Biol Chem 282:23655-23662.

Kiener PA, Rankin BM, Burkhardt AL, Schieven GL, Gilliland LK, Rowley RB, Bolen JB, Ledbetter JA (1993) Cross-linking of Fc gamma receptor I (Fc gamma RI) and receptor II (Fc gamma RII) on monocytic cells activates a signal transduction pathway common to both Fc receptors that involves the stimulation of p72 Syk protein tyrosine kinase. J Biol Chem 268:24442-24448.

Kim MS, Hong JH, Li Q, Shin DM, Abramowitz J, Birnbaumer L, Muallem S (2009) Deletion of TRPC3 in mice reduces store-operated Ca2+ influx and the severity of acute pancreatitis. Gastroenterology 137:1509-1517.

Kiselyov K, Xu X, Mozhayeva G, Kuo T, Pessah I, Mignery G, Zhu X, Birnbaumer L, Muallem S (1998) Functional interaction between InsP3 receptors and store-operated Htrp3 channels. Nature 396:478-482.

Kiyonaka S, Kato K, Nishida M, Mio K, Numaga T, Sawaguchi Y, Yoshida T, Wakamori M, Mori E, Numata T, Ishii M, Takemoto H, Ojida A, Watanabe K, Uemura A, Kurose H, Morii T, Kobayashi T, Sato Y, Sato C, Hamachi I, Mori Y (2009) Selective and direct inhibition of TRPC3 channels underlies biological activities of a pyrazole compound. Proc Natl Acad Sci U S A 106:5400-5405.

Kress M, Karasek J, Ferrer-Montiel AV, Scherbakov N, Haberberger RV (2008) TRPC channels and diacylglycerol dependent calcium signaling in rat sensory neurons. Histochem Cell Biol 130:655-667.

Lai JY, Cox PJ, Patel R, Sadiq S, Aldous DJ, Thurairatnam S, Smith K, Wheeler 
D, Jagpal S, Parveen S, Fenton G, Harrison TK, McCarthy C, Bamborough P (2003) Potent small molecule inhibitors of spleen tyrosine kinase (Syk). Bioorg Med Chem Lett 13:3111-3114.

Li HS, Xu XZ, Montell C (1999) Activation of a TRPC3-dependent cation current through the neurotrophin BDNF. Neuron 24:261-273.

Liao F, Shin HS, Rhee SG (1992) Tyrosine phosphorylation of phospholipase C-gamma 1 induced by cross-linking of the high-affinity or lowaffinity Fc receptor for IgG in U937 cells. Proc Natl Acad Sci U S A 89:3659-3663.

Lu SG, Zhang X, Gold MS (2006) Intracellular calcium regulation among subpopulations of rat dorsal root ganglion neurons. J Physiol 577: 169-190.

Ma HT, Patterson RL, van Rossum DB, Birnbaumer L, Mikoshiba K, Gill DL (2000) Requirement of the inositol trisphosphate receptor for activation of store-operated Ca2 + channels. Science 287:1647-1651.

Ma C, Zhang P, Sikand P, LaMotte RH, Gu Q (2009) Antigen-specific immune mechanisms of chronic pain. Soc Neurosci Abstr 35:459.5.

Ma C, Greenquist KW, Lamotte RH (2006) Inflammatory mediators enhance the excitability of chronically compressed dorsal root ganglion neurons. J Neurophysiol 95:2098-2107.

Mathsson L, Lampa J, Mullazehi M, Rönnelid J (2006) Immune complexes from rheumatoid arthritis synovial fluid induce FcgammaRIIa dependent and rheumatoid factor correlated production of tumour necrosis factoralpha by peripheral blood mononuclear cells. Arthritis Res Ther 8:R64.

McDougall JJ (2006) Arthritis and pain: neurogenic origin of joint pain. Arthritis Res Ther 8:220.

Miyano K, Morioka N, Sugimoto T, Shiraishi S, Uezono Y, Nakata Y (2010) Activation of the neurokinin-1 receptor in rat spinal astrocytes induces $\mathrm{Ca} 2+$ release from IP3-sensitive $\mathrm{Ca} 2+$ stores and extracellular $\mathrm{Ca} 2+$ influx through TRPC3. Neurochem Int 57:923-934.

Montell C (2008) In search of the holy grail for Drosophila TRP. Neuron $58: 825-827$

Moulin DE (1998) Pain in central and peripheral demyelinating disorders. Neurol Clin 16:889-898.

Naraghi M (1997) T-jump study of calcium binding kinetics of calcium chelators. Cell Calcium 22:255-268.

Neher E (1998) Vesicle pools and Ca2+ microdomains: new tools for understanding their roles in neurotransmitter release. Neuron 20:389-399.

Nimmerjahn F, Ravetch JV (2006) Fcgamma receptors: old friends and new family members. Immunity 24:19-28.

Nimmerjahn F, Ravetch JV (2007) Fc-receptors as regulators of immunity. Adv Immunol 96:179-204.

Nimmerjahn F, Ravetch JV (2008) Fcgamma receptors as regulators of immune responses. Nat Rev Immunol 8:34-47.

Oaklander AL (2008) Mechanisms of pain and itch caused by herpes zoster (shingles). J Pain 9:S10-S18.

Pedersen SF, Owsianik G, Nilius B (2005) TRP channels: an overview. Cell Calcium 38:233-252.

Pinto LG, Cunha TM, Vieira SM, Lemos HP, Verri WA Jr, Cunha FQ, Ferreira SH (2010) IL-17 mediates articular hypernociception in antigeninduced arthritis in mice. Pain 148:247-256.

Poteser M, Schleifer H, Lichtenegger M, Schernthaner M, Stockner T, Kappe CO, Glasnov TN, Romanin C, Groschner K (2011) PKC-dependent coupling of calcium permeation through transient receptor potential canonical 3 (TRPC3) to calcineurin signaling in HL-1 myocytes. Proc Natl Acad Sci U S A 108:10556-10561.

Qiu J, Fang Y, Rønnekleiv OK, Kelly MJ (2010) Leptin excites proopiomelanocortin neurons via activation of TRPC channels. J Neurosci 30:1560-1565.

Qu L, Zhang P, LaMotte RH, Ma C (2011a) Neuronal Fc-gamma receptor I mediated excitatory effects of IgG immune complex on rat dorsal root ganglion neurons. Brain Behav Immun 25:1399-1407.

Qu L, Zhang P, Ma C (2011b) Activation of neuronal Fc-gamma receptor I triggers a transient receptor potential-like current in the rat dorsal root ganglion neurons. Soc Neurosci Abstr 37:380.23.

Raybould NP, Jagger DJ, Kanjhan R, Greenwood D, Laslo P, Hoya N, Soeller C, Cannell MB, Housley GD (2007) TRPC-like conductance mediates restoration of intracellular $\mathrm{Ca} 2+$ in cochlear outer hair cells in the guinea pig and rat. J Physiol 579:101-113.

Sanchez-Miranda E, Ibarra-Sanchez A, Gonzalez-Espinosa C (2010) Fyn kinase controls FcepsilonRI receptor-operated calcium entry necessary for full degranulation in mast cells. Biochem Biophys Res Commun 391:1714-1720

Sastre-Garriga J, Montalban X (2003) APS and the brain. Lupus 12:877-882.

Shirakawa H, Sakimoto S, Nakao K, Sugishita A, Konno M, Iida S, Kusano A, Hashimoto E, Nakagawa T, Kaneko S (2010) Transient receptor potential canonical 3 (TRPC3) mediates thrombin-induced astrocyte activation and upregulates its own expression in cortical astrocytes. J Neurosci 30:13116-13129.

Sun JH, Yang B, Donnelly DF, Ma C, LaMotte RH (2006) MCP-1 enhances excitability of nociceptive neurons in chronically compressed dorsal root ganglia. J Neurophysiol 96:2189-2199.

Tang HB, Li YS, Arihiro K, Nakata Y (2007) Activation of the neurokinin-1 receptor by substance $\mathrm{P}$ triggers the release of substance $\mathrm{P}$ from cultured adult rat dorsal root ganglion neurons. Mol Pain 3:42.

Trebak M, Bird GS, McKay RR, Putney JW Jr (2002) Comparison of human TRPC3 channels in receptor-activated and store-operated modes: differential sensitivity to channel blockers suggests fundamental differences in channel composition. J Biol Chem 277:21617-21623.

Trebak M, Vazquez G, Bird GS, Putney JW Jr (2003a) The TRPC3/6/7 subfamily of cation channels. Cell Calcium 33:451-461.

Trebak M, St J Bird G, McKay RR, Birnbaumer L, Putney JW Jr (2003b) Signaling mechanism for receptor-activated canonical transient receptor potential 3 (TRPC3) channels. J Biol Chem 278:16244-16252.

van de Winkel JG, Tax WJ, Jacobs CW, Huizinga TW, Willems PH (1990) Cross-linking of both types of IgG Fc receptors, Fc gamma RI and Fc gamma RII, enhances intracellular free $\mathrm{Ca} 2+$ in the monocytic cell line U937. Scand J Immunol 31:315-325.

van Rossum D, Hanisch UK, Quirion R (1997) Neuroanatomical localization, pharmacological characterization and functions of CGRP, related peptides and their receptors. Neurosci Biobehav Rev 21:649-678.

Verri WA Jr, Cunha TM, Parada CA, Poole S, Liew FY, Ferreira SH, Cunha FQ (2007) Antigen-induced inflammatory mechanical hypernociception in mice is mediated by IL-18. Brain Behav Immun 21:535-543.

Verri WA Jr, Guerrero AT, Fukada SY, Valerio DA, Cunha TM, Xu D, Ferreira SH, Liew FY, Cunha FQ (2008) IL-33 mediates antigen-induced cutaneous and articular hypernociception in mice. Proc Natl Acad Sci U S A 105:2723-2728.

Wittkowski A, Richards HL, Griffiths CE, Main CJ (2007) Illness perception in individuals with atopic dermatitis. Psychol Health Med 12:433-444.

Wu LJ, Sweet TB, Clapham DE (2010) International Union of Basic and Clinical Pharmacology, LXXVI: current progress in the mammalian TRP ion channel family. Pharmacol Rev 62:381-404.

Xu SZ, Zeng F, Boulay G, Grimm C, Harteneck C, Beech DJ (2005) Block of TRPC5 channels by 2-aminoethoxydiphenyl borate: a differential, extracellular and voltage-dependent effect. Br J Pharmacol 145:405-414.

Zitt C, Obukhov AG, Strübing C, Zobel A, Kalkbrenner F, Lückhoff A, Schultz G (1997) Expression of TRPC3 in Chinese hamster ovary cells results in calcium-activated cation currents not related to store depletion. J Cell Biol 138:1333-1341. 